\section{The cause of university education}

SIR-The way in which the political ideology of a democratic government can make or mar the cause of higher education or university autonomy is best illustrated in the action of the governments of France (Nature 315, 172-173 \& 316, 5; 1985) and Britain (Nature 315, 265; 1985). In France, the present government has succeeded in freeing the universities from the overbureaucratization of higher education. The granting of absolute independence to the Comité National d'Evaluation des Universités (CNEU) so that it can make an objective evaluation of a university is a step in the right direction. This may free the university from day to day interference from political or bureaucratic authority. Furthermore, CNEU wants to lay equal emphasis on research and on teaching by individuals and groups within a university. This is most certainly a radical change from current practices in French universities, where too much emphasis has been laid either on research or on teaching in granting promotion to a member of the faculty. Promotion has depended on an individual's local political influence over the central machinery responsible for promotion.

The trend in British higher education has been the opposite. The present British government has inflicted maximum damage on the cause of university autonomy, of which the British have always been proud. Much has been written on the subject in editorials in Nature during the past two years. Nature has highlighted in a systematic manner the callous disregard of the present government for the sanctity of higher education. In this connection, the address delivered by Lord Attlee on the occasion of conferment of the Honorary Degree of Doctor of Laws by the University of Glasgow in 1951 is worth quoting:

"It has always been one of our proud boasts that our universities are free and are rightly jealous of any attempt by the State to extend its power over them. The administration by the University Grants Committee is a characteristic British device which while it passes muster with the financial critics of the House of Commons leaves the universities almost complete freedom to run their own affairs. In a democracy it is fundamental that thought should be free and that the inquiring and critical university spirit should be brought to bear on all affairs. The University must ever seek for the truth; it must never be a mere instrument in the hands of a government, a church or any political or economic group."

The respect in which the universities of Great Britain are held is mainly due to the freedom from governmental interference that they enjoy (or used to enjoy before the onslaught initiated by the present government), both constitutionally and actually.

In this crisis, the low-key position adopted by the university community is worrying. British academic institutions have almost surrendered to the political authority in its attempt to remove the autonomy of the universities. To free us from every kind of domination except that of reason is education in the real sense. This aim can be best achieved in an atmosphere of professional integrity where teachers are as free to speak on controversial issues as any other citizen of a free society. In Cardinal Newman's words, "A university education gives a man a clear conscious view of his own opinions and judgements, a truth in developing them, an eloquence in expressing them and a force in urging them".

University Louis Pasteur,

5 rue Blaise Pascal,

67084 Strasbourg Cedex, France

\section{PhD theses}

SIR-In regard to Beverly Halstead's cogent remarks (Nature 316, 760; 1985) about $\mathrm{PhD}$ theses, Linus Pauling must have set the standard when, in 1925, he submitted the reprints of five journal articles as his thesis.

Dana L. Roth

Sciences and Engineering Libraries,

California Institute of Technology,

Pasadena, California 91125, USA

\section{Greenhouse dilemma}

$\mathrm{S}_{\mathrm{IR}}$-The background to the "greenhouse effect" is well-known. Carbon dioxide from burning fossil fuels, deforestation and cement manufacture causes global temperature to increase by about $3^{\circ} \mathrm{C}$ each time the proportion of the gas in the atmosphere doubles. At the current rate of manmade $\mathrm{CO}$, production, the proportion will have doubled in about 230 years.

At the end of the last ice age, the global temperature increased naturally by only about $6^{\circ} \mathrm{C}$ with a corresponding sea-level rise of about 100 metres from melting ice in the following 2,000 years or so. By analgreenhouse effect of at least 12 metres in the next 230 years with a further 38 metres still to come, even if the rate of $\mathrm{CO}_{2}$ increase remains constant and there is no further rise thereafter. However, there is a close link between atmospheric $\mathrm{CO}_{2}$ increase and population size.

It seems inevitable, therefore, that the greenhouse effect will induce sea-level rises high enough to drown many if not most major cities of the world and much of their agricultural hinterlands within the lifetime of the sea defences presently designed at massive cost to protect them. Alternatively, the population size might be contained and then reduced to decrease manmade $\mathrm{CO}_{2}$ production. This would destroy the pensions and insurance structures of the developed world and family provision for the elderly of developing nations. ogy, this implies a sea-level rise due to the
We appear to face a dilemma. Social structures will not allow us to reduce the population. Current technology and economics will not provide a workable alternative to the consequent continuing generation of $\mathrm{CO}_{2}$ with its associated sealevel rise and massive incursions.

If we accept the greenhouse calculations, should we not be embracing their conclusions more urgently in the planning of relevant engineering and financial structures? On the other hand, if we choose to disbelieve the warnings, why are we paying dearly for them with public money?

BRUCE DENNESS

Bureau of Applied Sciences Ltd, Wydcombe Manor, Whitwell, Isle of Wight PO $382 \mathrm{NY}, \mathrm{UK}$

\section{Metric system}

SIR-Having grown up in the United States and lived in Britain, as well as visiting and living in several metric lands, I think A.A. Berezin (Nature 317, 762; 1985) has missed the point of D.C. Jolly's rather sensible letter on the metric system. A measurement system must first of all be a means by which one can orient oneself to the physical world. Any system satisfying this condition is, in that sense, as adequate as any other. I do not need to know how many square feet there are in an acre; I do need to know that an acre is a generous lot for a house but insufficient land to farm. A mile does not mean 5,280 feet to me. It means a long walk or a short drive. In my laboratory, I use the metric system exclusively, not because I believe it necessarily better but because it is the means by which I was trained to orient myself on scientific matters. When I do a physical examination of a patient, I measure and weigh in metric but report the results to the anxious human in feet and pounds. If Berezin ever told an American mother her baby had a temperature of 37 degrees, he would quickly understand my meaning. For myself as well, centigrade provides too narrow a gauge to describe bodily comfort compared to Fahrenheit, and also a fever of $104^{\circ} \mathrm{F}$ has a zing to it that $40^{\circ} \mathrm{C}$ could never match. The comforting security in tradition can sometimes more than compensate for the inconvenience of technical inefficiency.

Being universal, science needs a universal idiom and if that mandates metric, so be it. But how one sees one's personal world and describes it to others is quite another matter. For those purposes, the British-American system of measurements suits me and millions more just fine. What divides nations and peoples is not how they measure things but intolerance for the ways of others.

Division of Medical Genetics,

School of Medicine,

University of Pittsburgh,

Pittsburgh, Pennsylvania 15213, USA 